\title{
Legal Policy in Village-Owned Enterprises After the Enactment of the Law on the Job Creation in The Framework of Village Society Welfare*
}

\author{
Fatkhul Muin ${ }^{1}$ \\ Faculty of Law Universitas Sultan Ageng Tirtayasa Serang-Banten \\ 10.15408/jch.v9i3.22191
}

\begin{abstract}
The essence of law is to provide welfare to society. Law as a tool of social engineering for society makes people obey it. Dynamic legal developments encourage progress towards society from various aspects of people's lives. One of them, the enactment of Law No. 11 of 2020 on Job Creation, encourages changes to the order of setting norms that affect other laws that are affected by it. One of those affected by the Job Creation Act is the establishment of BUMDes (Village-Owned Enterprises). Through the provisions of Article 117 and Article 185 b of Law Number 11 of 2020 concerning Job Creation, the government needs to establish a derivative norm that regulates Village-Owned Enterprises. In this provision, it is stated that Village Owned Enterprises, hereinafter referred to as BUMDes, are legal entities established by the village and/or together with villages to manage businesses, utilize assets, develop investment and productivity, provide services, and/or provide other types of business for the maximum welfare of the Village community. In a nutshell, the existence of Village-Owned Enterprises aims to prosper the village community, with the type of business sector owned and support the productivity of rural communities based on village community empowerment. In this study, a legal approach was used with the aim of exploring legal policies towards BUMDes with the enactment of the Job Creation Act.
\end{abstract}

Keywords: Job Creation Act, BUMDes, welfare

* Received: July 15, 2021, revised: December 22, 2021, accepted: December 23, 2021, Published: December 30, 2021.

1 Fatkhul Muin is a Doctor in Law, Faculty of Law Universitas Sultan Ageng Titayasa, https://orcid.org/0000-0001-9305-8065, Scopus Author ID: 57210388068 Email: fatkhulmuin@untirta.ac.id. 


\section{Kebijakan Hukum Pada Badan Usaha Milik Desa Setelah Berlakunya Undang-Undang tentang Penciptaan Lapangan Kerja Dalam Rangka Kesejahteraan Masyarakat Desa Abstrak}

Adanya hukum sebagai alat rekayasa sosial bagi masyarakat. Karenanya, eksistensi hukum menjadikan masyakat taat terhadap hukum. Perkembangan hukum yang bersifat dinamis, mendorong kemajuan terhadap masyarakat dari berbagai aspek kehidupan masyarakat, salah satunya dengan disahkannya Undang-Undanag Nomor 11 Tahun 2020 tentang Cipta Kerja mendorong perubahan terhadap tatanan pengaturan norma-norma yang memberikan pengaruh terhadap undang-undang lain yang terdampak dengan Undang-Undang cipta kerja tersebut. Salah satu yang terdampak dengan adanya Undang-Undang Cipta Kerja adalah tentang pembentukan BUMDes (Badan Usaha Milik Desa). Melalui ketentuan Ketentuan Pasal 117 dan Pasal 185 huruf b Undang-Undang Nomor 11 Tahun 2020 tentang Cipta Kerja, maka pemerintah perlu membentuk norma turunannya yang mengatur tentang Badan Usaha Milik Desa. Dalam ketentuan peraturan tersebut bahwa Badan Usaha Milik Desa yang selanjutnya disebut BUMDes adalah badan hukum yang didirikan oleh desa dan/atau bersama desa-desa guna mengelola usaha, memanfaatkan aset, mengembangkan investasi dan produktifitas, menyediakan jasa pelayanan, dan/atau menyediakan jenis usaha lainnya untuk sebesarbesarnya kesejahteraan masyarakat Desa. Penelitian ini menggunakan metode penelitian kualitatif dengan pendekatan peraturan perundang-undangan dan literatur, dengan tujuan mengeksplorasi kebijakan hukum terhadap BUMDes dengan disahkannya Undang-Undang Cipta kerja. Hasil penelitian menyatakan bahwa keberadaan Badan Usaha Milik Desa bertujuan untuk mensejahterakan masyarakat desa, dengan jenis bidang usaha yang dimiliki dan menunjang produktivitas masyarakat desa dengan didasarkan kepada pemberdayaan masyarakat desa.

Kata Kunci: UU Cipta Kerja, BUMDes dan Kesejahteraan

\section{Правовая политика в отношении сельских предприятий после принятия Закона о создании рабочих мест для благосостояния сельских общин}

Аннотация

Существование права является инструментом социальной инженерии для общества.

Следовательно, существование закона заставляет людей подчиняться закону. Динамичное правовое развитие, способствующее прогрессу в направлении общества из различных аспектов жизни людей, одним из которых является ратификация Закона № 11 от 2020 года о создании рабочих мест, поощряющего изменения в порядок регулирования норм, которые влияют на другие законы, на которые распространяется закон о создании рабочих мест. Одним из факторов, затронутых законом о создании рабочих мест, является создание BUMDes (сельских предприятий). В соответствии с положениями статьи 117 и статьи 185 буква b Закона № 11 от 2020 года о создании рабочих мест правительству необходимо установить производную норму, регулирующую деятельность сельских предприятий. В положениях постановления сельские предприятия, далее именуемые BUMDes, являются юридическими лицами, учрежденными деревнями и/или вместе с деревнями для управления предприятиями, использования активов, развития инвестиций и повышения производительности, предоставления услуг и / или предоставления других виды бизнеса для наибольшего благополучия деревенской общины. В этом исследовании используется качественный метод исследования с законодательным и литературным подходом с целью изучения правовой политики в отношении BUMDes c принятием Закона о создании рабочих мест. Результаты исследования показали, что существование сельских предприятий направлено на процветание деревенской общины с помощью частного сектора бизнеса и поддержки производительности сельских общин на основе расширения прав и возможностей деревенских общин.

Ключевые слова: Закон о создании рабочих мест, BUMDes (сельские предприятия) и социальное обеспечение. 


\section{A. INTRODUCTION}

Legal reality illustrates the essence of law to achieve justice for everyone. Substantially, the understanding of law is constructed on the basis of the values that develop in society. Redbruch stated that the value in the ideals and purposes of the law serves as a regulatory and constitutive measure. It is the understanding of the law that ultimately realizes the true meaning of law to achieve justice for the society (Absori, et. al, 2015, p 74). Justice is analogous to the highest goal of the ideals of the law itself, with justice, the goals of a nation can be achieved at every level. Therefore, for regulative and constitutive as the basis in the development of law, every society must provide the ideals of justice.

The development and realization of law in people's lives will certainly face various challenges, both caused by internal factors and external factors of society. In fact, the law will be good if the people accept it voluntarily. On the other hand, the law will be bad if the people cannot accept it, because they cannot protect the interests of the community. Thus, the law and the public interest must be in balance, in the sense that the law was created to protect the public interest. (Nur Rohim Yunus, 2012, p 3). Therefore, that in essence, law and society must become one unit and they must accept each other.

The enactment of Law number 11 of 2020 has provided changes for the acceleration of development in all sectors of people's lives. Efforts to empower the community are trimmed down in the provisions of other laws, and regulated in one law that covers all sector provisions, thus affecting other laws because they are considered to be overlapping. The effectiveness of Law no. 11 of 2020 leads to trimming the bureaucratic system, services, and community empowerment. Basically, this is a form of transformation from the rule of law to moral supremacy, as follows.

\section{Table I}

Legal Transformation to Moral Transformation

\begin{tabular}{|l|l|l|}
\hline No. & \multicolumn{1}{|c|}{ Rule of Law } & \multicolumn{1}{c|}{ Rule of Moral } \\
\hline 1 & Conflict Resolution & Peace \\
\hline 2 & Legislation & Moral and Justice \\
\hline 3 & Procedure & Empathy \\
\hline
\end{tabular}




\begin{tabular}{|l|l|l|}
\hline 4 & Legal Justice & Substantial Truth \\
\hline 5 & Bureaucracy & Commitment \\
\hline
\end{tabular}

(Suteki and Galang Taufani, 2018, p. 35)

The transformation of the rule of law into the rule of morals is an attempt to create a legal order that is not only oriented to legal certainty, but rather to create an order of life that is oriented that the law provides benefits to society in general.

In law, the slogans Ubi Sociates Ibi Ius, Fiat Jutitia Ruat Caelum, and others, emphasize that even in the simplest society, the existence of legal norms as a social institution has actually become a qonditio sine quanon for the sustainability of that society as an entity. However, does it mean that the existing law in a society has become something systemic? In other words, has the existing law in society been built into a legal system? To answer this question, of course, it must first be ascertained what is meant by a legal system, so that it can be used as a benchmark. It is possible that what exists in a society are separate legal rules, which are not interconnected. Or, even if they are related, they do not support each other, instead they weaken each other (Paisol Burlian, 2015, p. 1). If we place the law in a position as an institution that is always intertwined with the community, then it is a necessity that the law will accept and process all the existences that come from its environment. (Satjipto Rahardjo, 2006, pp.43-44). In general, norms have two tangible sides, including: (Yulies Tiena Masriani, 2016, p 3) 1). The command is a must for everyone to do something, because the result is considered good; and 2). Prohibition is a necessity for someone not to do something, because the result is seen as bad.

Pancasila and the 1945 Constitution of the Republic of Indonesia (UUD 1945) stipulate that the goal of the establishment of the Republic of Indonesia is to create a prosperous, just, wealthy, equitable society, both materially and spiritually. In line with this goal, Article 27 paragraph (2) of the 1945 Constitution stipulates that "Every citizen has the right to work and a decent living for humanity". Therefore, the state needs to make various efforts or actions to fulfill the rights of citizens to get a decent job and living. Fulfillment of the right to work and a decent living is in principle one of the important aspects of national development. National development is carried out in the context of developing Indonesian people as a whole and the development of Indonesian society as a whole to create a prosperous, just, wealthy, equitable society, both materially and spiritually based on Pancasila and the 1945 Constitution of the Republic of Indonesia.The current condition of Indonesia 
shows that the very high increase in the number of productive age is not matched by an increase in the quality of human resources and the availability of jobs. As a result, many Indonesians are jobless. The low quality of human resources makes job seekers unable to compete in the formations needed by the job field or companies. On the other hand, we have to admit that job opportunities are very limited. Starting from these conditions, the government must make various strategic efforts in order to fulfill the rights to work and a decent life as mandated in the 1945 Constitution.

Indonesian law is the whole of the rules and principles based on justice that regulates human relations in society that is currently in effect in Indonesia. As a national law, the validity of Indonesian law is limited to certain legal areas, and is aimed at certain legal subjects and objects. Indonesian legal subjects are Indonesian citizens and foreign citizens domiciled in Indonesia. Meanwhile, the objects of Indonesian law are all movable or immovable objects, tangible or intangible objects, which are located within the jurisdiction of Indonesia. Indonesian law as a tool of society serves to integrate the interests of community members so as to create neatness and order. Because the law regulates the relationship between humans and humans, humans and society and vice versa, the measure of the relationship is: justice. Indonesian law is essentially a system, which consists of elements or parts that are interrelated and related to each other to achieve goals based on the 1945 Constitution and imbued with the Pancasila philosophy. As a system, the Indonesian legal system has provided a means to resolve conflicts between its elements. The Indonesian legal system is also open. Therefore, in addition to factors outside the system such as economic, political and social influences, the Indonesian legal system is also open to other interpretations. (Paisol Burlian, 2015, pp 11$12)$.

One of the government's efforts to face the challenges is through a legislative policy, by initiating and proposing an omnibus law on job creation. On February 12, 2020, the Presidential Letter (Surpres) and the draft of the omnibus law were officially handed over by the government through the Coordinating Minister for Economic Affairs, Airlangga Hartanto, to the Chair of the House of Representatives, Puan Maharani. The conception of regulatory reform is expected to provide quality improvement as a substantial legal system. Given that the most basic meaning of legislative reform is "to make better" or "return to a former good state", with the omnibus law, the arrangement of the legal system in Indonesia is getting better (Agus Suntoro, 2021, p. 2). Omnibus law is a law in which the substance is to revise and/or revoke many laws. This concept developed in common law countries with 
Anglo Saxon legal systems such as the United States, Belgium, England, and Canada. The concept of omnibus law offers to fix problems caused by overregulation and overlapping. If the problem is handled in a regular way, it will take quite a long time and cost a lot of money. Not to mention that the process of designing and forming laws and regulations often creates deadlocks or is not in accordance with interests (Antoni Putra, 2020, p. 2). Therefore, it is necessary to harmonize efforts in legal politics, in order to create a better legal order. In John Austin's thinking, law as an order, then basically that existing law must be permanent and logical, as in his book, The Province of Jurisprudence Determined, Austin states, "A law is a command which obliges a person or persons... Laws and other command are said to proceed form superiors, and to bind or oblige inferiors." (Darji Darmodiharjo and Shidarta, 1999, p 113).

In fact, according to Firman Freaddy Busroh, the omnibus law in its application has many benefits, as follows: (Rizal Irvan Amin et., al. 2020, p. 195)

1. As a legal instrument to resolve regulatory conflicts effectively, efficiently, and quickly;

2. Can simplify bureaucratic processes that were previously long and complicated;

3. Harmonize policies at the central and regional levels so as to improve the investment climate;

4. Improving the quality of coordination between governments as well as between related agencies

5. and institutions, both at the central and regional levels because it has been regulated in an integrated omnibus law policy;

6. The level of ease of doing business is getting higher because licensing arrangements are becoming more effective, efficient, and centralized;

7. Provide guarantees of legal certainty and legal protection for decision makers and the public.

Development is a method to improve people's welfare. The village is part of the government agency that is closest in implementing development, because it is directly related to the community. In the village development effort, the government gives direct authority to the village government to manage its area independently, one of which is through economic institutions in the village, namely the Village-Owned Enterprises. In this case, the Business Entity is classified as a macro business in encouraging the improvement of the 
community's economy, (Riyan Pradesyah and Albara, p 157), with the VillageOwned Enterprises as a form of village community empowerment and welfare development for rural communities.

\section{B. METHODS}

A research is a series of activities carried out to study and analyze problems. This research examines the legal policies of Village-Owned Enterprises after the enactment of Law no. 11 of 2020 on Job Creation and the regulation in Article 117 and Article 185 (b) of Law Number 11 of 2020 concerning job creation provides changes to the existence of Village-Owned Enterprises as legal entities. Therefore, this research used a legal approach method by examining the position of Village-Owned Enterprises after the enactment of Law no. 11 of 2020 on Job Creation.

\section{RESULTS AND DISCUSSION}

\section{Village-Owned Enterprises in the Dimensions of the Job Creation Law}

Government regulations can have both positive and negative impacts on the process of innovation and competitiveness. Regulatory reforms are primarily carried out to provide a positive influence or impact on innovation and competitiveness. Regulatory reform is expected to ensure that laws and regulations in all fields of activity are fully responsive to changes in the economic, social and technological conditions that surround them. The regulatory process considers the regulatory impact associated with innovation as well as the implications of technological change for regulatory reasons and design. Regulations and regulatory reforms can affect technology, as well as can affect the innovation process. Regulation directly affects the innovation process, while technical innovation and changes have a significant impact on regulation. Success can be achieved through regulatory reform efforts by taking into account the relationship between regulation and innovation. Economic regulation is intended to increase market efficiency in delivering goods and services that affect the innovation process. Social regulations protect the environment and the safety and health of the wider community, their designs can encourage or hinder innovation. Administrative regulations govern the practical functioning of the public and private sectors--setting some of the basic conditions for technological progress. 
Sustainable development encourages changes to the order of life for society. Harmony between norms and people's needs is required for social balance to occur in the life of the nation and state. Increasing the positive influence of regulation on innovation is carried out through the following efforts. (Academic Paper on the Job Creation Law)

1. Understanding regulatory or technological relationships, regulatory processes in the economic, social and administrative fields, having awareness of the impact of technological changes;

2. Introducing competitiveness. In all sectors of the economy, interenterprise competitiveness is important for innovation;

3. Streamlining regulations. For economic efficiency and innovation, regulatory reform seeks to eliminate duplication, inhibiting and inefficient regulations, especially for UMKM (MSMEs) including cooperatives;

4. Using a technological approach;

5. Striving for international harmonization. The State pursues greater compatibility of regulation to remove uncertainty, inefficiency, and market bottlenecks that can slow down innovation.

Table II

\section{Types of Regulation}

\begin{tabular}{|c|l|l|}
\hline No & Types of Regulation & \multicolumn{1}{c|}{ Description } \\
\hline $\mathbf{1}$ & Economic Regulation & $\begin{array}{l}\text { Economics regulation is generally intended to } \\
\text { increase market efficiency in delivering goods } \\
\text { and services, including restrictions imposed by } \\
\text { the government on company decisions on } \\
\text { prices, quantities, and incoming and outgoing } \\
\text { services. }\end{array}$ \\
\hline $\mathbf{2}$ & Social Regulation & $\begin{array}{l}\text { Social regulation is intended to protect the } \\
\text { welfare and rights of the wider community. It } \\
\text { includes protection of the environment, health } \\
\text { and safety at work, workers' rights, and buyers } \\
\text { from fraudulent behavior or incompetence of } \\
\text { sellers. }\end{array}$ \\
\hline $\mathbf{3 .}$ & Administrative & Administrative regulation relates to \\
\hline
\end{tabular}




\begin{tabular}{|l|l|l|}
\hline Regulation & $\begin{array}{l}\text { government management of activities in the } \\
\text { public and private sectors. It includes } \\
\text { regulations relating to taxes, business } \\
\text { operations, distribution systems, health care } \\
\text { administration, and intellectual property } \\
\text { rights. }\end{array}$ \\
\hline
\end{tabular}

\section{Source: Academic Paper on the Job Creation Law}

The issue of society empowerment is inseparable from the rural society empowerment. Law No. 6 of 2014 specifically regulates village society and village government as well as the existence of Village-Owned Enterprises as the basis for developing village community businesses, based on village community empowerment and services for village communities. Through the provisions of Law no. 6 of 2014 concerning Villages, there have been significant changes in village development. This is because the portion of village funds is large and increases every year as an effort to build village infrastructure based on the local wisdom.

The use of village funds continues to increase from year to year. In 2015, the central government spent 20.67 trillion of funds for village development. Until recently, village funds transferred to each village through the local government have reached 70 trillion. The increase in village funds is an effort to empower and develop village communities based on the sense of people's togetherness. One of the ways to allocate village funds is through the development of legal policies in the Village-Owned Enterprise sector that can encourage the potential of village communities. The provision of village fund assistance carried out by the village government to village-owned enterprises is basically to improve and provide services through village funds from the central government to be jointly managed by village communities with full responsibility.

The concept of civil society or national wealth creation is not too different from the characteristics of the welfare state. The government still has to intervene for the welfare of the nation, but still pay attention to the existence of the market. In this third pattern, the community and the nation are expected to be more active in carrying out these activities. Meanwhile, the government is expected to be only a facilitator. However, the government is still required not to let go of a condition which, although favored by business actors, turns out to be detrimental to the public interest. Thus, the concept of the welfare state remains inseparable for this nation. The concept of the welfare state in which the state is represented by the government (state administration) as the 
administrator of the government's duties, does not only make and maintain the law, or only maintain order and peace. Instead, their duties are bigger than that, which is organizing public interests, such as people's health, education, housing, etc. The government is also given the task and authority to act on its own initiative in solving all community problems in order to protect the public interest. In carrying out the public interest, in general terms, according to Stelinga, the state administration has the authorities to: 1). Make policy determination; 2). Make arrangements/regulations; 3). To protect; 4). Conduct justice, and 5). Provide services to citizens.

Meanwhile, according to Brown, public interest activities are carried out by providing public services which are activities that use public authority, and are carried out to meet the satisfaction of public needs. (Academic Paper on the Job Creation Law).

The principle of Recognition of the Village in the Village Law is contextual, constitutional, and is the result of political negotiations between the government, DPR, DPD, and also the Village. The meaning of the principle of recognition is as follows: 1). The village or what is called by another name, as a customary law community unit, is a different entity from the legal community unit called a region; 2). The village or what is called by another name is an entity that existed before the proclamation of the Republic of Indonesia in 1945 and already has the original structure and origin rights; 3 ). The village or what is called by another name is a part of the diversity of Indonesia so that it cannot be forced to be similar with the others; 4 ). The villages or what is called by other names, in historical trajectories, is structurally an arena for exploitation of land and residents and have been treated unfairly from feudalism, colonialism, to authoritarianism; 5). The constitution has given a mandate to the state to recognize and respect the Village or what is called by another name as a unit of customary law community and their traditional rights; 6). In accordance with the constitutional mandate [Article 18B paragraph (2) of the 1945 Constitution of the Republic of Indonesia], the state, the private sector (economic actors) and third parties (NGOs, universities, international donor agencies and so on) must recognize and respect the existence of the Village as a community unit. Law; 7). The existence of the Village includes the rights of origin (innate as well as local initiatives that develop) the territory, government, local regulations and institutions, local institutions, cultural identity, community unity, Village initiatives and Village assets; 8). The concept of recognizing and respecting the Village means actions to utilize, support, and strengthen existing Village institutions, rather than highlighting interventions (interference) and actions to force and kill Village institutions. 
Examples of actions that are contrary to the Principle of Recognition (recognition and respect) are: 1). The government and the private sector carry out development projects in the Village without dialogue or without obtaining Village approval; 2). Outside parties form Village community groups without Village approval; and so forth.

The regional autonomy granted to the district and city levels is considered to have not played a significant role in the progress of national development. This is due to various obstacles, one of which is that development in villages in the area has not been well distributed. Therefore, wider autonomy and closer to the community is needed. Responding to these problems, Law Number 6 of 2014 concerning Villages (UU Desa) was issued, which started a new chapter of national development from the government unit closest to the community, which is the Village. The central government, in recent years, has been committed to supporting village development. The president's program to provide funds of one billion per village is a form of the president's concern for building up to the village level. Rural development has two main objectives: long-term and short-term goals. The long-term goal of village development is to increase employment, business opportunities, and increase income, based on the approach of human development, business development, and environmental development.

A village, according to Article 1 point 1 of the Law, is a legal community unit that has territorial boundaries that are authorized to regulate and manage government affairs, the interests of the local community based on community initiatives, origin rights, and/or traditional rights that are recognized and respected in the government system of the Unitary State of the Republic of Indonesia. The Village Administration which is structurally under the regency/municipality remains part of the regency/city regional government. However, the management of the village is carried out independently, the local government only acts as a supervisor and advisor in achieving regional development goals through village empowerment. One of the village development efforts begins with the development of village resources and finances so that village governance can be realized independently. (Alfiansyah, 2021, p 213) The government together with the House of Representatives (DPR) in 2020 made Law Number 11 of 2020 concerning Job Creation (UU Cipta Kerja). The Job Creation Law regulates various sectors and changes various articles in various laws and regulations, one of which is the Village Law. Article 117 of the Job Creation Law amends Article 1 point 6 of the Village Law. Previously, in the Village Law, BUMDes was referred to as a business entity. However, in the Job Creation Law, BUMDes is referred to as a legal entity. 
These changes are based on, among other things, the problems that have been described previously and with these changes it will make changes to the status of BUMDes and their implications in society (Alfiansyah, 2021, p 213). The development of Village-Owned Enterprises, of course, encourages the sustainability of rural society empowerment.

The purpose of the enactment of the Job Creation Law is as stated in its preamble. The job creation law is expected to be able to absorb as many Indonesian workers as possible, in a climate of increasingly fierce competition and the demands of economic globalization. Regulations related to the convenience, protection, and empowerment of cooperatives and micro, small and medium enterprises, improvement of the investment ecosystem, and acceleration of national strategic projects, including increasing protection and welfare of workers spread across various sectoral laws have not yet been able to meet the needs law for the acceleration of work creation. Therefore, changes need to be made. The philosophical basis for the enactment of the Job Creation Law is based on Article 4, Article 5 paragraph (1), Article 18, Article 18A, Article 18B, Article 20, Article 22D paragraph (2), Article 27 paragraph (2), Article 28D paragraph ( 1) and paragraph (2), and Article 33 of the 1945 Constitution of the Republic of Indonesia. There is a regulation regarding BUMDes in the Job Creation Law, namely in Article 117 of the Job Creation Law, which changes the provisions in Law Number 6 Year 2014 regarding Village in Article 1 (6). Village-Owned Enterprises, hereinafter referred to as BUMDes, are legal entities established by villages and/or together with villages to manage businesses, utilize assets, develop investment and productivity, provide services, and/or provide other types of businesses for as many as much for the welfare of the village community. (Alfiansyah, 2021 p 216). This is the basis for the fact that the existence of a Village-Owned Enterprise is an effort to prosper the village community itself.

Law Number 11 of 2020 on Job Creation has affirmed the position of BUMDes as a legal entity established by the Village and/or together with other villages to manage business, utilize assets, develop investment and productivity, provide services, and or provide other types of business for the maximum welfare of the village community. With the status as a legal entity, the role of BUMDes/Joint BUMDes together is increasingly important as a consolidator of community products/services, producers of various community needs, community business incubators, public service providers, and various other functions. BUMDes/BUMDes can be a contributor to the Village's original income. Therefore, in the future, BUMDes/BUMDes is believed to encourage village independence. 
This Government Regulation is the legal basis for the establishment and management of Village-Owned Enterprises (BUMDes)/Joint Village-Owned Enterprises (joint BUMDes) as legal entities with arrangements that are adjusted to corporate principles in general, but still places the spirit of kinship and mutual cooperation as main pillar. For this reason, in this Government Regulation, it is regulated in detail the organizational apparatus of the BUMDes/Joint BUMDes consisting of Village Consultations/Inter-Village Deliberations, advisors, operational staff, and supervisors; the authority and duties of each device in a professional, efficient and effective manner, as well as accountable. The spirit of kinship and mutual cooperation is manifested in real terms by placing the Village Conference/Inter-Village Deliberation as the highest organ in BUMDes/Joint BUMDes decision making. It was emphasized that decisions were made based on deliberation to reach consensus. This policy is in line with the mandate of the Village Law which places the Village Deliberation as a forum for deliberation between the village consultative body, village government, and elements of the community to deliberate and agree on strategic matters in the administration of village governance. Thus, the Village Consultation/Inter-Village Deliberation becomes a real manifestation of deliberative democracy in the village economy. Therefore, the welfare of society as a whole will remain the main goal of BUMDes/Joint BUMDes, not just individual well-being. This Government Regulation contains regulations regarding the establishment of BUMDes/Joint BUMDes, articles of association and bylaws, organization and employees, work program plans, ownership, capital, assets and loans, business units, procurement of goods/services; ease of taxation and retribution, cooperation, accountability, sharing of business results, losses, termination of business activities, as well as BUMDes/Joint BUMDes development and development (Yuni Andono Achmad). With the promulgation of this government regulation, it is expected that the Village Owned Enterprises can develop rapidly.

\section{Legal Policy in the Framework of Developing Village-Owned Enterprises as an Effort for Village Welfare}

The main factor in the law to play a role in economic development is whether it is able to create stability, predictability and equity. The first two are prerequisites for an economic system to function. Included in the scope of stability, legal potential to balance and accommodate competing interests. The need for predictable laws is considered important for a country where most of the people, for the first time, enter into economic relations beyond the 
traditional social environment. Aspects of justice, such as equal treatment and standardized patterns of government behavior, are needed to maintain market mechanisms and prevent excessive bureaucracy (Academic Paper on Job Creation Law). The existence of the law must be the standard for efforts to create welfare for the community in general, in accordance with the ideals of the Indonesian nation. BUMDes is a form of community participation as a whole which was established based on the Village Regulation concerning the Establishment of BUMDes. This was also established on the basis of consideration of the distribution of village community initiatives, village potential development, management, utilization of village potential, financing and village government assets, which were handed over to be managed by BUMDes. (Edy Yusuf Agunggunanto, et.al. 2016, p 70). The existence of Village Owned Enterprises is an effort to create welfare for the community.

Economic development in rural areas has long been carried out by the government through various programs. The government is expected to create a business climate that encourages healthy economic development, both in improving the welfare of members and the surrounding community and in building the national economic system as an economic organization. One of the new approaches that are expected to stimulate and move the wheels of the economy in rural areas is through the establishment of economic institutions that are fully managed by rural communities. Therefore, the existence of this economic institution is not controlled by certain groups who have large capital in the village. Instead, it is owned by the the village and jointly controlled by the people. The main objective is to improve the community's economic standard of living. The development of the Village-Owned Enterprise cannot be separated from the competition it faces with other economic actors. BUMDes which is a pillar of economic activity in the village that functions as a social and commercial institution. BUMDes as a social institution stands for the interests of the community through its contribution to the provision of social services. Meanwhile, as a commercial institution, BUMDes aims to make a profit by offering local resources (goods and services) to the market. In carrying out its business the principles of efficiency and effectiveness must always be emphasized. BUMDes as a legal entity, is formed based on the applicable laws and regulations, and in accordance with the agreements developed in the village community. (Chindy Sasauw, et.al, 2018)

BUMDes requires good management by fulfilling its management principles. The components involved in it: village government, management members, Village Consultative Body (BPD), district government, and the 
people, need to understand these principles. There are 6 (six) principles in managing BUMDes, as follows. (Afifa Rachmanda Filya, 2019, p 21-22)

1. Cooperative. All components involved in BUMDes must be able to work together for the development and survival of their business. BUMDes in Bojonegoro sub-district has several components involved, they are the village government, BUMDes managers, BPD, and the district government through the sub-districts. They must coordinate and work together to improve the development of BUMDes management.

2. Participatory. All components involved in BUMDes must be willing to voluntarily or be asked to provide support and contributions that can encourage the progress of the BUMDes business. BUMDes in Bojonegoro sub-district has several components involved, they are the village government, BUMDes managers, the Village Consultative Body (BPD), and the district government through the sub-districts. They must support each other in every business activity carried out by BUMDes.

3. Emancipatory. All components involved in BUMDes must be treated equally regardless of class, ethnicity, and religion. BUMDes in Bojonegoro sub-district has several components involved, they are the village government, BUMDes managers, the Village Consultative Body (BPD), and the district government through the sub-districts. They must receive equal treatment regardless of the individual background of the component.

4. Transparent. Activities that affect the public interest must be known by all levels of society easily and openly. In carrying out its business activities, BUMDes must be willing to provide information and not prevent anyone from getting the information. Therefore, it is necessary to design information systems and other activities that are related to the public's interests.

5. Accountable. All business activities must be accountable both technically and administratively. Every business activity carried out by BUMDes must be accounted for in order to maintain the principle of accountability. Accountability reports are usually submitted every period by the BUMDes manager.

6. Sustainable. Business activities must be developed and preserved by BUMDes members. To be able to survive in business competition, 
BUMDes must continue to innovate and maintain the quality of its business, which is assisted by all components of BUMDes. This is related to the development of turnover, profit/loss, condition of goods/services, service system, promotion efforts, location and business expansion of BUMDes.

Basically, the existence of BUMDes is part of an effort to create community products that can be marketed by the community through legal entities managed by institutions with the capital from the village income budget, be it from village funds or from the village treasury. From a product perspective, of course it is closely related to the pattern of social relations. It means that the products produced by the community are part of the community's productivit. (Anthony Giddens, 1971, p 35). In reality, developing BUMDes is not easy. The various problems faced are challenges for BUMDes. Some of the problems include communication problems between management, business unit management, personnel problems, and village potentials that have not been utilized. (Emma Rahmawati, 2020, p 2). BUMDes is one of the pillars that functions to support micro-economic actors who develop at the village level. The rationale for the presence of BUMDes is first, being able to overshadow economic activities that are managed collectively by the village. Second, this strategy is chosen so that groups of micro-economy activists that are being developed by the government through direct assistance, can be connected. So far, direct assistance identified through the PNPM program to Bappenas cannot be separated from capacity building programs, individual and group business development, and assistance oriented to meeting basic needs. Community empowerment activities that are closely related to the economy are expected to receive positive appreciation from BUMDes. Another factor that underlies the strengthening of BUMDes is the reality that the potential of human resources that have been gathered in economic groups often encounter difficulties when they want to distribute products across regions. On average, they do not have broad and adequate access, so they are at risk of being stopped at the production stage. (Hari Fitrianto, 2016, p. 915).

BUMDes is a village business institution that is managed by the community and village government in an effort to strengthen the village economy and is formed based on the needs and potential of the village. BUMDes was born as a new approach in an effort to improve the village economy based on the needs and potential of the village. The establishment of BUMDes is based on Law Number 6 of 2014 concerning Villages. BUMDes as a legal entity, was formed based on the applicable laws and regulations, and in accordance with the agreements that were built in the village community. The 
form of BUMDes can vary in every village in Indonesia. These various forms are in accordance with the local characteristics, potentials, and resources of each village. Further regulation of BUMDes is regulated through a Regional Regulation (Perda). Currently, not many BUMDes are well developed. The main causes include the lack of professional management of BUMDes. Law Number 6 of 2014 concerning Villages has opened the door to move the economy in the village. It must be realized that villages need to increase their expertise and skills in managing Village-Owned Enterprises. (I Made Ega Prayoga Kusuma, et.al). In order to realize a just village community order, regulations are needed that provide certainty for village communities to regulate village management as part of village potential. In simple terms, this potential is based on the following legal framework.

\section{Diagram I}

\section{Legal Framework for Developing Village Potential}
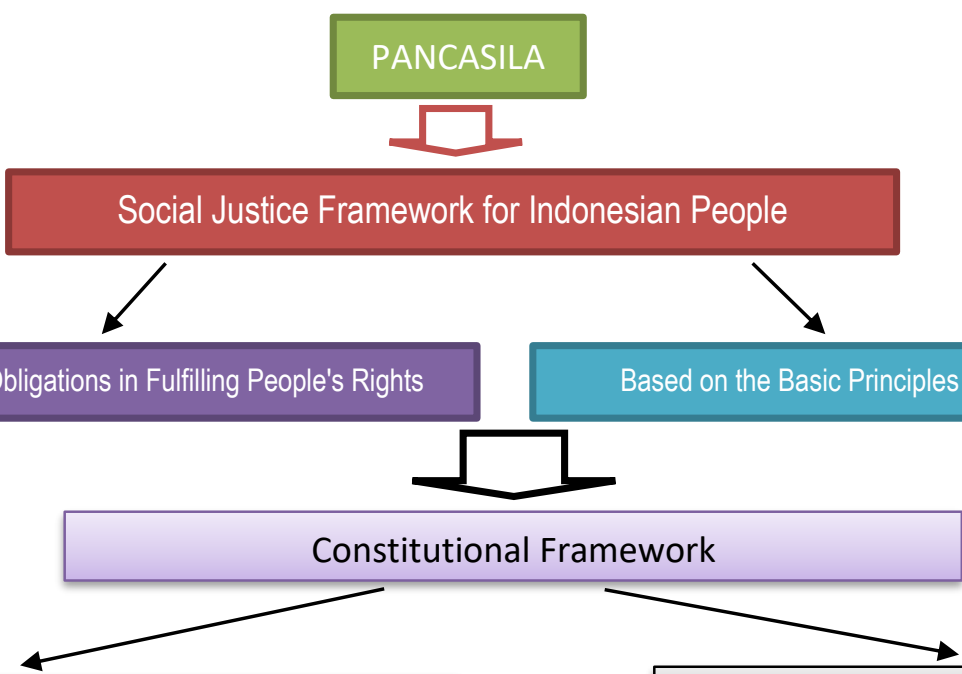

Law No. 11 of 2020 on Job Creation

III Inn 6 of 2014 nn Villane.
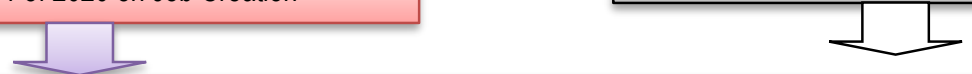

Government Reaulation (PP) Number 11 of 2021 concernina Villaae-Owned Enterbrises (BUMDes)

Implementing the provisions of Article 117 and Article 185(b) of Law Number 11 of 2020 on Job Creation

Village Community Empowerment 
Law Number 11 of 2020 on Job Creation has confirmed the position of BUMDes as a legal entity established by a village and/or together with other villages to manage businesses, utilize assets, develop investment and productivity, provide services, and/or provide services. other types of business for the maximum welfare of the Village community. With the status as a legal entity, the role of BUMDes/Joint BUMDes is increasingly important as a consolidator of community products/services, producers of various community needs, community business incubators, public service providers, and various other functions. BUMDes/Joint BUMDes can be a contributor to village original income. Therefore, in the future, BUMDes/Joint BUMDes are believed to encourage village independence. This Government Regulation serves as the legal basis for the establishment and management of BUMDes/Joint BUM Des as a legal entity with arrangements adapted to corporate principles in general, but still places the spirit of kinship and mutual cooperation as the main pillars in its management. For this reason, this Government Regulation regulates in detail the BUMDes/Joint BUMDes organizational apparatus consisting of Village Consultations/Inter-Village Deliberations, advisors, operational staff, supervisors, authorities and duties of each BUMDes/joint BUMDes organizational management, work procedures and relationships between BUMDes/joint BUMDes Organizational devices, as well as provisions to ensure that BUMDes/joint BUMDes organizational devices can carry out their duties and authorities in a professional, efficient and effective, and accountable manner.

The partnership relationship between the government, especially the village government, with the private sector and the community in supporting the existence of village-owned enterprises as strengthening the village economy can run well if it is based on the principles that support it, as follows. (Coristya Berlian Ramadana, et.al. p 1072): 1). Mutual trust and respect; 2). Autonomy and sovereignty; 3 ). Complementary; 4). Openness and accountability.

In supporting the existence of Village-Owned Enterprises for strengthening the village economy, these principles are very important. If the principle is implemented in accordance with the regulations that exist between the government and the private sector as well as the community, the partnership will run well too. In general, the development of BUMDes in Indonesia is divided into three parts, as follows. 


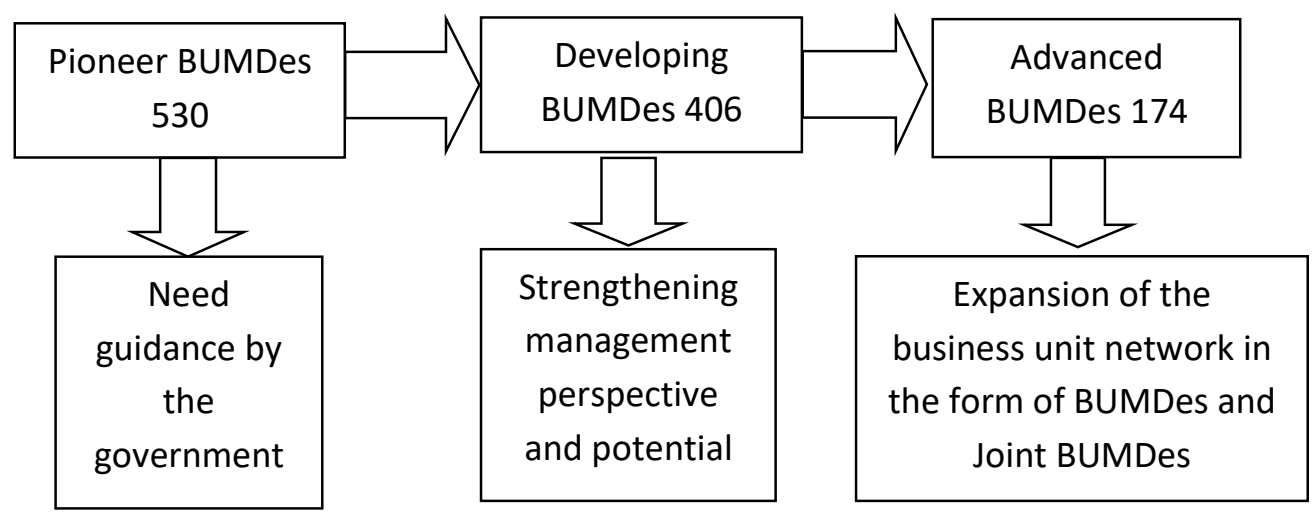

Source: https://bumdes.id/id/

The development of BUMdes is an effort to create prosperity for the community. Therefore, BUMDes/Joint BUMDes aims to:

1. carry out economic business activities through business management, as well as investment development and economic productivity, and village potential;

2. carry out general service activities through the supply of goods and/or services as well as meeting the general needs of the village community, and managing village food barns;

3. get a profit or net profit for increasing the village's original income as well as developing the maximum benefit from the economic resources of the village community;

4. utilize village assets to create added value; and developing a digital economy ecosystem in the village.

In addition, to create an independent BUMDes, there are at least several main characteristics of BUMDes, as follows: (Akhmad Yani, et., al. 2019, p. 168169): 1). This business entity is owned by the village and managed jointly; 2 ). The capital is from the village by $51 \%$ and from the community by $49 \%$ through equity (shares); 3). Its operation uses a business philosophy rooted in local culture; 4). Business fields are based on market potential and information; 5). The benefits obtained are shown to improve the welfare of members (equivalent to capital) and the community through village policies; 6). Facilitated by the Provincial Government, Regency Government, and Village Government; 7). Operations are jointly controlled by BPD, Village Government, and Members. 
In order to create a good BUMDes, basic principles are needed in the context of managing BUMDes. In general, there are several principles for managing BUMDes. There are 6 (six) principles in managing BUMDes, as follows.

1. Cooperative. All components involved in BUMDes must be able to work together for the development and survival of their business.

2. Participatory. All components involved in BUMDes must be willing to voluntarily or be asked to provide support and contributions that can encourage the progress of the BUMDes business.

3. Emancipatory. All components involved in BUMDes must be treated equally regardless of class, ethnicity, and religion.

4. Transparent. Activities that affect the public interest must be known by all levels of society easily and openly.

5. Accountable. All business activities must be accountable both technically and administratively.

6. Sustainable. Business activities must be developed and preserved by BUMDes members.

So far, we are familiar with the concept of living in a society, nation and state, but have not touched the locus of the village. The issuance of the Village Law has placed the village as a collective forum in state and community life, thus creating the concept of Village Tradition as a concept of living in a society and state in the village realm. Some of the core ideas of the Village Tradition are as follows: 1). A village is the basis of social capital that fosters a tradition of inclusive solidarity, cooperation, self-help, and mutual cooperation that transcends the exclusive boundaries of kinship, ethnicity, religion, sect, or the like; 2). A village has power and government which contains the authority and accountability to regulate and manage the interests of the community; 3 ). A village is local economic driver that is capable of carrying out the function of protection and distribution of basic services to the community. (Anom Surya Putra, 2015, p 10)

The concept of Village Tradition is one of the fundamental ideas that accompanied the establishment of BUMDes. This Village Tradition parallels the wealth of social and political capital and affects the resilience and sustainability of BUMDes. The core ideas of the Village Tradition in the establishment of BUMDes are as follows. 
1. BUMDes needs social capital (cooperation, solidarity, trust, and the like) for business development that reaches out to a more inclusive and wider social network.

2. BUMDes develops in inclusive politics through the practice of Village Deliberations as the highest forum for the development of village economic enterprises driven by BUMDes.

3. BUMDes is a form of collective village economic enterprise between the village government and the village community. The collective village economic efforts carried out by BUMDes contain elements of social business and economic business.

4. BUMDes is a business entity mandated by the Village Law as an effort to accommodate all activities in the economic sector and/or public services managed by the village and/or inter-village cooperation.

5. BUMDes becomes a learning arena for villagers in forging managerial capacity, entrepreneurship, good village governance, leadership, trust and collective action.

6. BUMDes transforms programs initiated by the government (government driven; government projects) into "village-owned". (Anom Surya Putra, 2015, p 11-12)

The fulfillment of the general welfare and village economy must be like a solid backbone. The development of rural economic resilience requires awareness and concerted efforts of all components at every macro, meso, micro level, even at each level that can be uniquely defined. Not only economic resilience, but also how development is also able to define village adaptive welfare as welfare in accordance with local wisdom. Welfare that does not "copy" or "follow" the parameters of the village or other places. Welfare that "adjusts" to what is given by God in the form of nature and the produce of the earth and the uniqueness of its people. Therefore, support from the state, industry players, to academia and the community in general must be more real and actionable for the village. One of them is through empowering the potential of the village as a sustainable solution for the welfare of the village in the future. One form of empowerment from the government, that is village autonomy, allows the village to manage its resources independently, one of which is through Village-Owned Enterprises (BUMDES). The management of BUMDES is carried out by the village government together with the community. (P.L. Rika Fatimah, 2018, p 123). The main focus to create prosperity for rural communities lies in the active participation of the 
community. Therefore, with the regulation of BUMDes in Law no. 11 of 2020 concerning Job Creation, encourages the creation of a professional BUMDes management system based on community welfare.

In essence, that the existence of village-owned enterprises will encourage the economic progress of the village community, therefore it is necessary to have legal policies issued by the government and local governments. with the Law no. 11 of 2020 concerning Job Creation, encouraging synergy between the government and local governments in the context of developing village-owned enterprises as an effort to create social justice for rural communities which is the mandate of Pancasila and the constitution.

\section{CONCLUSION}

Basically, the village as part of the smallest government order in the government system in Indonesia, has a strategic role in the context of developing community welfare. The promulgation of Law no. 6 of 2014 concerning villages encourages the empowerment of village communities, especially with regard to the existence of Village-Owned Enterprises in which there is capital sourced from village finances. In general, Village Owned Enterprises are divided into three categories, they are pioneering, developing and advanced. The number of pioneer BUMdes reached 530, developing BUMDes 406 and advanced BUMDes 174. In 2020, with the enactment of Law no. 11 of 2020 concerning Job Creation, in the provisions of Article 117 and Article 185 (b) of Law Number 11 of 2020 concerning Job Creation, the government establishes a derivative norm. This is in the context of developing Village-Owned Enterprises, which is ratified by Government Regulation of the Republic of Indonesia Number 11 of 2021 on Village-Owned Enterprises. Substantively, the establishment of Village Owned Enterprises consisting of BUMDes and Joint BUMDes aims to build the welfare of rural communities.

\section{REFERENCES}

\section{Books:}

Anthony Giddens, (1971), Capitalism and Modern Social Theory, An analysis of the writings of Marx, Durkheim and Max Weber, Cambridge University Press.

Anom Surya Putra, (2015), Serial Bahan Bacaan Buku 7 Badan Usaha Milik Desa: Spirit Usaha Kolektif Desa, Diterbitkan oleh: Kementerian Desa, 
Pembangunan Daerah Tertinggal, Dan Transmigrasi Republik Indonesia.

Absori, et.al. (2015) Hukum Profetik, Kritik Terhadap Paradigma Hukum NonSistematik, Yogyakarta, Genta Publishing.

Darji Darmodiharjo dan Shidarta, (1999), Pokok-Pokok Filsafat Hukum, Apa dan Bagaimana Filsafat Hukum Indonesia, Jakarta: Gramedia Pustaka Utama.

Nur Rohim Yunus, (2012), Restorasi Budaya Hukum Masyarakat Indonesia, Jurisprudance Press. Bogor.

Suteki dan Galang Taufani, (2018), Metodologi penelitian Hukum, Filsafat, Teori dan Praktek, Depok Rajagrafindo Persada.

Satjipto Rahardjo, (2006), Hukum Dalam Jagad Ketertiban, Bacaan Mahasiswa Program Doktor Ilmu Hukum Universitas Diponegoro, Jakarta, UKI Press.

Yulies Tiena Masriani, (2016), Pengantar Hukum Indonesia, Jakarta: Sinar Grafika.

\section{Journal Articles:}

Alfiansyah, (2021), Status Badan Usaha Milik Desa Sebagai Badan Hukum Atas Diundangkannya Undang-Undang Cipta Kerja, Jurnal Ilmu Sosial dan Pendidikan, Vol. 5. No. 2. http://dx.doi.org/10.36312/jisip.v5i2.1991

Antoni Putra, (2020), Penerapan Omnibus Law Dalam Upaya Reformasi Regulasi, Jurnal Legislasi Indonesia Vol 17 No. 1.

Agus Suntoro, (2021) Implementasi Pencapaian Secara Progresif Dalam Omnibus Law Cipta Kerja, Jurnal HAM, Volume 12, No. 1.

Afifa Rachmanda Filya, (2019) Optimalisasi Pengelolaan Badan Usaha Milik Desa (Bumdes) Dalam Meningkatkan Pades Di Kecamatan Bojonegoro Kabupaten Bojonegoro Provinsi Jawa Timur (Studi Kasus Di Desa Sukorejo Kecamatan Bojonegoro), Jurnal Eksekutif, Vol 3, No 3.

Akhmad Yani, et.,al. (2019), Peran dan Fungsi Badan Usaha Milik Desa Dalam Meningkatkan Kegiatan Ekonomi Masyarakat Pedesaan (Di Desa Karuminting Kecamatan Sungai Raya Kabupaten Bengkayang), Proceeding of SATIESP.

Coristya Berlian Ramadana, et.al., KEBERADAAN BADAN USAHA MILIK DESA (BUMDES) SEBAGAI PENGUATAN EKONOMI DESA (Studi di Desa Landungsari, Kecamatan Dau, Kabupaten Malang), Jurnal Administrasi Publik (JAP), Vol. 1, No. 6.

Chindy Sasauw, et.al. (2018), Efektivitas Badan Usaha Milik Desa (Bumdes) Dalam Meningkatkan Masyarakat Di Desa Lenganeng Kecamatan Tabukan Utara Kabupaten Kepulauan Sangihe, Jurnal eksekutif Jurnal Jurusan Ilmu Pemerintahan Volume 1 No. 1. Accessed through 
https://ejournal.unsrat.ac.id/index.php/jurnaleksekutif/article/view/219 $\underline{40}$

Emma Rahmawati, (2020), Analisis Pengelolaan Badan Usaha Milik Desa (Bum Desa) Di Kabupaten Bandung Barat, Jurnal Ilmiah Ekonomi Bisnis Volume 25 No. 1. http://dx.doi.org/10.35760/eb.2020.v25i1.2386

Edy Yusuf Agunggunanto, et.al. (2016), Pengembangan Desa Mandiri Melalui Pengelolaan Badan Usaha Milik Desa (Bumdes), Jurnal Dinamika Ekonomi dan Bisnis, Vol 13 No. 1.

Hari Fitrianto, (2016), Revitalisasi Kelembagaan Bumdes Dalam Upaya Meningkatkan Kemandirian dan Ketahanan Desa di Jawa Timur, Jejaring Administrasi Publik, Vol. 8, No. 2. Accessed through. http://journal.unair.ac.id/download-fullpapersadmp95658b964ffull.pdf.

I Made Ega Prayoga Kusuma, et.al, Pembentukan Dan Pengelolaan Badan Usaha Milik Desa Yoga Mesari Desa Mengwi Menurut Peraturan Daerah Kabupaten Badung Nomor 1 Tahun 2015 Tentang Pendirian Dan Pengelolaan Badan Usaha Milik Desa, Accessed through https://ojs.unud.ac.id/index.php/Kerthanegara/article/download/40644/ $\underline{24649}$.

Paisol Burlian, (2015), Sistem Hukum di Indonesia, Fakultas Dakwah Dan Komunikasi Universitas Islam Negeri (UIN) Raden Fatah Palembang.

P.L. Rika Fatimah, (2018), Mengembangkan Kualitas Usaha Milik Desa (QBUMDES) untuk Melestarikan Ketahanan Ekonomi Masyarakat dan Kesejahteraan Adaptif: Perancangan Sistem Kewirausahaan Desa dengan Menggunakan Model Tetrapreneur, Jurnal Studi Pemuda Volume 7 Nomor 2. http://doi.org/10.22146/studipemudaugm.39551

Rizal Irvan Amin et.,al. (2020), OMNIBUS LAW ANTARA DESIDERATA DAN REALITA (Sebuah Kajian Legislative Intent), Jurnal Hukum Samdura Keadilan, Volume 15, Nomor 2.

Yuni Andono Achmad, Kajian Kelembagaan Badan Usaha Milik Desa (BUMDes) Pasca Peraturan Pemerintah nomor 11 Tahun 2021, accessed through http://yuniando.staff.gunadarma.ac.id/Downloads/files/86348/Penelitia n-Kajian+Kelembagaan+BUMDes.pdf.

\section{Laws:}

Academic Paper on Job Creation Law.

Law No. 11 of 2020 concerning Job Creation

Law No. 6 of 2016 About Village

Government Regulation No. 11 of 2021 on Village-Owned Enterprises 